Przegląd Badań Edukacyjnych Educational Studies Review

ISSN 1895-4308

nr 23 (2/2016), s. 25-44

ORYGINALNE

ARTYKUtY

BADAWCZE

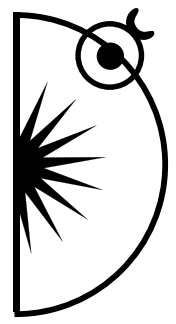

Jan Polcyn

Państwowa Wyższa Szkoła Zawodowa im. Stanisława Staszica w Pile, e-mail: Jan.Polcyn@pwsz.pila.pl

Maciej Gawrysiak

Państwowa Wyższa Szkoła Zawodowa im. Stanisława Staszica w Pile, e-mail: mgawrysiak@pwsz.pila.pl

\title{
Wskaźnik edukacyjny oraz poziom rozwoju społecznego jako tło wyników egzaminacyjnych na poziomie gimnazjalnym i ponadgimnazjalnym
}

http://dx.doi.org/10.12775/PBE.2016.071

\section{Education Index and Level of Social Development as a Background for Examination Results on the Lower and Upper Level of Secondary School}

\begin{abstract}
In recent years, there has been an the increase in the number of publications discussing the need for investment in human capital as early as in the early stages of education. The often shown theory is that at the later stages of education it is an individual predisposition that has a greater impact than the support of the government system does. Therefore, the article draws attention to the role of preschool education, whose high quality could become a new target of such support. The study aimed to determine the effect of preschool education on learning outcomes at lower and upper secondary education. To accomplish this task, measures of determining the level of participation in preschool education and examination results at the end of lower and upper secondary schools aggregated at the district level (NTS-4) were used. The study also examined the relationship between the education index and the level of social development. The obtained preliminary results indicate significant differences between the level of social development on all analyzed levels of education and the education index. The results indicate further research which will allow for confirming the identified dependencies.
\end{abstract}


Keywords: education index, preschool education, exam results, quality of education, economy of education

\section{Wstęp}

Celowość działań edukacyjnych w zakresie kreowania kapitału ludzkiego może być bezpośrednio analizowana poprzez stopień zainteresowania edukacją oraz wynikami, jakie osiągają studenci i uczniowie. Efekty te mogą być widoczne jako stopa bezrobocia lub wyniki uzyskane na egzaminach końcowych poszczególnych etapów kształcenia. Okazuje się jednak, że częstokroć na późniejszych etapach edukacji wiele większą rolę odgrywają indywidualne predyspozycje, a wyniki zdają się coraz mniej zależeć od wpływu z zewnątrz. Analiza literatury wskazuje, że na wyniki nauczania może wpływać wcześniejsza ścieżka edukacyjna, szczególną rolę upatruje się tutaj w edukacji przedszkolnej. Uwzględniając doniesienia wskazujące na znaczną rolę edukacji przedszkolnej w późniejszych etapach kształcenia, sformułowano cel niniejszej pracy.

Praktycznym problemem polskiego społeczeństwa w ostatnich latach jest brak dostatecznej ilości miejsc w przedszkolach. Wobec takiego problemu interesujący może być wpływ wspomnianego utrudnienia na dalsze etapy edukacyjne młodzieży, zwłaszcza w kontekście kreowanego kapitału ludzkiego społeczeństwa.

Celem przeprowadzonych badań jest określenie wpływu edukacji przedszkolnej na efekty kształcenia na poziomie gimnazjalnym i ponadgimnazjalnym. Realizacja celu zostanie wsparta zbadaniem zależności pomiędzy wskaźnikiem edukacyjnym a poziomem rozwoju społecznego.

\section{Efekty edukacji przedszkolnej}

Badania wpływu edukacji przedszkolnej na dalsze etapy edukacyjne nie są prowadzone często, nie są też znane wyniki takich analiz prowadzone w warunkach polskich. Było to powodem odwoływania się do doniesień światowych obejmujących omawianą problematykę. Wobec rzadkości wspomnianych analiz powoływano się na doniesienia literaturowe z różnych regionów świata.

Wyniki badań przeprowadzonych w 1995 r. z udziałem uczniów posiadających doświadczenie przedszkolne wykazały bardzo duży, pozytywny wpływ na wyniki uczniów osiągane w testach (Daniels, 1995). Wykazano, że jest to efekt dużo silniejszy od przewagi, jaką daje wiek czy przynależność do grupy społecznej i ma on swoje odzwierciedlenie we wszystkich dziedzinach, tj. czytaniu, 
pisaniu, operacji na liczbach. Także doświadczenia wynikające z opieki przedszkolnej i tzw. playgroups (mniej formalnych przedszkoli dla dzieci poniżej 5 roku życia) w grupie mają silny pozytywny efekt w porównaniu do dzieci nie uczęszczających do przedszkola. Porównywanie grup o różnych możliwościach edukacyjnych, a jednocześnie o różnych tłach społecznych, może prowadzić jednak do nieprecyzyjnych wyników.

Badania dotyczące wpływu edukacji przedszkolnej na wyniki egzaminacyjne na późniejszych etapach kształcenia przeprowadzono także w Urugwaju (Aguilar, Tansini, 2012). Autorzy tych badań wskazują, że istnieją doświadczalne dowody na silny pozytywny wpływ edukacji przedszkolnej na wyniki dzieci w pierwszej klasie, oraz że występuje efekt długofalowy, który również jest pozytywny pomimo, że słabsze oddziaływanie widoczne jest jeszcze po 6 latach.

Badania długoterminowego wpływu edukacji i opieki przedszkolnej na osiągnięcia kognitywne i rozwój, obejmujące około 2500 dzieci i przeprowadzone w Anglii, wykazały małe, lecz znaczące pozytywne efekty edukacji przedszkolnej (z ang. preschool education). Rezultaty te dotyczą osiągnięć dzieci w wieku 10 lat w czytaniu i matematyce. Mierzono również ich stopniowe postępy, sukcesywnie w wieku od 6 do 10 lat. Analizowano także jak długo dzieci uczęszczały do przedszkoli (liczba miesięcy) i jakiej jakości te przedszkola były oraz ich efektywność (analiza umiejętności czytania i matematyki). Wyniki wskazały, że głównym predyktorem przyszłego powodzenia dzieci jest w dużej mierze poziom „kwalifikacji matki” wyrażany jako jej poziom wykształcenia i warunki do nauki stworzone w domu (Sammons i in., 2008).

Jak potwierdzają także badania z Botswany, uczniowie, którzy uczęszczali do przedszkoli radzą sobie lepiej w szkole (Taiwo, Tyolo, 2002). Zwrócono jednak uwagę, iż przekłada się to także na łatwość, z jaką przyswajana jest wiedza w pierwszych klasach, a co za tym idzie następuje proces szybszego uczenia się. Z kolei badania dokonane w Iranie pomimo tego, że potwierdzają różnice pomiędzy wynikami dzieci w wynikach testów (użyto tzw. Social Maturity Scale) i są one znaczące, jednakże nie wystarczająco, by rekomendować w tym kraju edukację przedszkolną jako obowiązkową (Tatari i in., 2013).

Inne interesujące długofalowe badania dotyczące dzieci z Wielkiej Brytanii skupiały się z kolei na ich możliwościach poznawczych w wieku 11, 14 i 16 lat oraz zależności tych cech od uczestnictwa w edukacji przedszkolnej (Apps, Mendolia, Walker, 2013). W badaniach tych stwierdzono pozytywny efekt zwłaszcza u dziewczynek i dzieci z rodzin o niższym poziomie zaplecza socjoekonomicznego. Pozostałe osiągnięcia niezwiązane ze zdolnościami kognitywnymi były słabsze. 
Badania osiągnięć uczniów z uwzględnieniem podziału na płeć na wyspach Barbados i St. Vincent wykazywały również tendencje powiązane z omawianym tematem (Kutnick, 2000). Mianowicie potwierdzono lepsze wyniki w nauce dziewcząt, a jednocześnie wykazano, że wyniki zależą od tego, czy uczniowie uczęszczali do przedszkola i od typu szkoły. Jednocześnie przedstawiono związek z wykonywanym przez rodziców zawodem.

Opublikowane w 2014 r. badania wskazują na problem, z jakim spotkali się angielscy ustawodawcy, czyli rozczarowaniem niskimi wynikami uczniów w Wielkiej Brytanii. Porównując lukę w matematycznych osiągnięciach pomiędzy Anglią i Wschodnią Azją wykazano, że pomimo wyższego średniego wyniku z matematyki w krajach Azji Wschodniej, różnica ta nie zwiększa się przy porównaniu wyników uczniów w wieku 10 i 16 lat. Autorzy wnioskują, że reformowanie systemu szkolnictwa średniego nie jest najlepszym sposobem na poprawienie tych wyników edukacyjnych. Będzie nim wcześniejsza interwencja na etapie edukacji przedszkolnej lub podstawowej (Jerrim, Choi, 2014).

Badania przeprowadzone $\mathrm{u}$ dzieci z ADHD wykazały powiązanie tego zjawiska z problemami w nauce w szkole (Washbrook, Propper, Sayal, 2013). W badaniach tych próbowano znaleźć zależność pomiędzy wiekiem przedszkolnym a dorosłością. W tym konkretnym przypadku zbadano dzieci 3-letnie i ich wyniki w wieku 16 lat. Wykazano, że hiperaktywność i brak uważności niosą za sobą problemy, które mogą zaowocować gorszymi wynikami w wieku 16 lat. Być może interwencja w wieku przedszkolnym i tutaj mogłaby przynieść pozytywne efekty. Inne badania pokazują, że edukacja przedszkolna rozwija także cechy związane z samoregulacją, jak i zdolności wykonawcze (kognitywne) niezbędne w planowaniu działań (Sylva, 2014).

\section{Programy interwencyjne w przedszkolach - przykłady i efekty}

Długofalowy wpływ edukacji przedszkolnej badano także w Północnej Irlandii. Badanie tego wpływu polegało na przeprowadzeniu programu efektywnej edukacji przedszkolnej (The Effective Pre-school Provision in Northern Ireland $(E P P N I)$ ). Omawiany program obejmował wieloletnie studia nad rozwojem dzieci od 3 do 11 roku życia. Badano wyniki z języka angielskiego i matematyki. Przedszkola o wysokiej jakości wykazały trwały efekt mający swoje odzwierciedlenie w osiągnięciach w wynikach testów z języka angielskiego i matematyki. W przypadku samej matematyki zaobserwowano zwiększony postęp wykraczający poza szkołę podstawową. Jak wykazały badania, w wielu testach 
dzieci z najlepszych przedszkoli osiągały lepsze wyniki (w niektórych przypadkach nawet zwiększając prawdopodobieństwo osiągnięcia wysokiego rezultatu nawet 4-krotnie) (Melhuish i in., 2013).

Trudny moment przejścia z przedszkola do szkoły podstawowej może sugerować postawienie pytania: Jaki jest najlepszy wiek, aby wspierać rozwój i edukować dzieci? Zwłaszcza w kontekście progu 7 lub 6 lat określającego moment rozpoczęcia edukacji podstawowej. Zastosowany w Portugalii program SEL (Social and Emotional Learning) był analizowany pod kątem efektywności właśnie po zastosowaniu go zarówno w przedszkolach, jak i w szkołach podstawowych. Program ten przede wszystkim znacznie poprawił u dzieci relacje z rówieśnikami, ich zachowanie w szkole, zdolności społeczne, wiedzę emocjonalną, umiejętność zdobywania wiedzy oraz umiejętność dopasowania zachowań społecznych niezależnie od płci. Podobnie jak we wcześniejszych doniesieniach, wskazuje się tutaj także na wpływ poziomu wykształcenia rodziców (jako czynnik poziomu socjoekonomicznego dziecka), a który może ograniczyć zakres zysków, jakie może uzyskać dziecko z tego konkretnego programu interwencyjnego. Wykazano także, że poziom umiejętności dziecka przed uczestnictwem w programie nie miał istotnego wpływu na wszystkie, oprócz jednego z badanych mierników, oraz, że ważne jest, by analizować charakterystykę rodzin dzieci (Correia, Marques-Pinto, 2016).

Jedną z form interwencji mającej na celu poprawienie edukacji dzieci w wieku przedszkolnym mogą być wizyty domowe przynoszące szczególną korzyść dzieciom z rodzin patologicznych (Lagerberg, 2000).

Także w rejonie Indii podjęto próby interwencyjnego polepszenia edukacji przedszkolnej, której ewaluacja doprowadziła do wniosków dotyczących ich wpływu na rozwój psychosocjologiczny dzieci (Ade i in., 2010). Otrzymano wniosek, iż istotnie statystyczny wpływ na rozwój dzieci w tym okresie mają wiek dziecka, wykształcenie matki, płeć, dochód rodziny oraz obecność specjalnego programu interwencyjnego ( $\mathrm{w}$ obszarach, w których podjęto interwencję osiągnięto wynik testów wyższy o 10 punktów), co dowodzi celowości tychże działań.

Przy niektórych programach interwencyjnych nie zawsze osiągano jednak wyraźną poprawę. Takim przykładem jest Values Education Programme $\mathrm{z}$ Turcji. Chociaż zauważono różnice $\mathrm{w}$ formie wzrostu umiejętności przed i po testach, to mimo 3-miesięcznego programu nie zauważono wyraźnej różnicy pomiędzy grupą eksperymentalną i grupą kontrolną (Dereli-Iman, 2014). Może to świadczyć o potrzebie dłuższej pracy z dziećmi. 


\section{Jakość przedszkoli i kierunki inicjatyw ustawodawczych}

Badanie jakości kształcenia na etapie przedszkolnym jest elementem wielu badań na całym świecie, wyniki tych badań są zróżnicowane. Badania wykonane w Brazylii, mające na celu zidentyfikowanie różnic w wynikach uczniów na początku edukacji podstawowej wykazały powiązania rezultatów z jakością przedszkola (szkoły ECE), do której uczęszczały dzieci. Badanie to oparte było o egzamin humanistyczny uczniów, którzy uczęszczali do ECE, jak i tych, którzy nie skorzystali z kształcenia w przedszkolu. Dzięki wielopoziomowej analizie, korzystając $\mathrm{z}$ wielu zmiennych, wykazano silny pozytywny wpływ uczęszczania do przedszkola na wyniki uczniów. Do pozostałych istotnych zmiennych autorzy zaliczyli także wiek dziecka, poziom wykształcenia matki, dochód rodziny i wyniki wskaźnika jakości edukacji podstawowej IDEB (Index of Basic Education Quality (Indice de Desenvolvimento da Educacao Basica), dzieci które skorzystały z ECE. Autorzy twierdzą, że młodszy wiek (6 a czasem i 5 lat) lub opóźnienie w rozpoczęciu kształcenia w efekcie objawia się znacząco gorszymi wyniki od pozostałych uczniów w klasie (Campos i in., 2011).

Jak wskazują inni autorzy, ustawodawcy w Anglii powinni brać pod uwagę jakość przedszkoli, chcąc zapobiec zagrożeniom, jakie mogą dotknąć bardzo małe dzieci (mogą regulować efekty wynikające z ryzyka na poziomie dziecka, np. niska waga przy narodzinach, i te związane z rodziną, np. poziom biedy) (Hall i in., 2009).

Rzadko w badaniach analizowane są grupy obejmujące dzieci młodsze niż 3 rok życia. Przeprowadzono analizę wpływu tego typu edukacji na zdolność czytania u uczniów 4 klasy (na podstawie wyników tzw. Progress in International Reading Literacy Study (PIRLS) z roku 2011. Wyniki wskazały na fakt dużego pozytywnego wpływu zarówno wczesnej edukacji, jak socjoekonomicznego i kulturalnego zaplecza rodzin na umiejętność czytania (Gonzalez-Betancor, Lopez-Puig, 2015).

Zgodnie z badaniami przeprowadzonymi na Łotwie także rodzaj doświadczeń zawodowych nauczycieli przedszkola jest kluczem do rozwoju osobowości dzieci i ich przyszłego sukcesu. Jak się okazuje, to nie tylko profesjonalizm, ale także szczerość, empatia i poczucie odpowiedzialności zawodowej, jaką jest edukowanie dzieci, odgrywa zasadniczą rolę. Ważne tutaj jest także stworzenie dzieciom możliwości samokształcenia. Badania wykazują, że właśnie osoby z najbliższego otoczenia tworzą podstawę rozwoju poprzez przekazanie fundamentów systemu wartości. To oni także budują atmosferę bezpieczeństwa emocjonalnego, które wpływa na poczucie pewności siebie i wiary w swoje 
umiejętności, co prowadzi do aktywnej i otwartej postawy wobec świata (Samusevica, 2013).

Zdarza się nawet, że rodzice w poszukiwaniu najlepszego przedszkola dla dziecka gotowi są zmienić swoje miejsce zamieszkania (Hansen, 2014). Zjawisko takie przeanalizowano w Wielkiej Brytanii. Autorzy pokazali zależność pomiędzy kosztem domów położonych blisko dobrych szkół podstawowych a stopniem zaangażowania rodziców, w sensie gotowości do zwiększenia wydatków, nawet zanim dziecko osiągnie wiek pozwalający mu na rozpoczęcie kształcenia podstawowego. Pokazuje to duże zapotrzebowanie na wysoką jakości edukacji.

\section{Równość szans}

Silna zależność osiągnięć edukacyjnych dzieci od poziomu wykształcenia ich rodziców jest bardzo często poddawana dyskusji w literaturze naukowej. O ile jednak uczęszczanie do przedszkoli często nie doprowadza do zrównania wyników dzieci, to bez uczęszczania do nich różnice pomiędzy wynikami edukacyjnymi byłyby jeszcze większe (Becker, 2011).

Duży problem w edukacji stanowi frekwencja szkolna. Ma to szczególne znaczenie u dzieci z grup wykluczenia społecznego i mniejszości narodowych. Długotrwałe studium tego problemu zostało wykonane na terenie Australii wśród dzieci Aborygenów (Taylor, 2010). Badanie wpływu przerywanej frekwencji na zajęciach w nieobowiązkowych przedszkolach jest często podstawą do dyskusji o bezpośrednim wpływie tego zjawiska na wykluczenie społeczne. Okazuje się bowiem, że stosowane programy mające na celu zwiększenie tej frekwencji mają bezpośrednie przełożenie na zmniejszenie zagrożenia wykluczeniem społecznym, a jednocześnie w tym wypadku zwiększają szanse na lepsze wyniki na dalszych etapach nauki i w dorosłym życiu.

Silny nacisk na potrzebę skupienia się na edukacji przedszkolnej pokazano także dokonując szerokiej analizy publikacji australijskich i międzynarodowych, z których wynika, iż istnieje silna potrzeba wypełniania luki obejmującej edukację przedszkolną, intencjonalną, ukierunkowaną na przyszłe osiągnięcia (Davis, 2009).

Uwzględniając doświadczenia Stanów Zjednoczonych i Wielkiej Brytanii, zwiększono nakłady na jakość kształcenia w Korei dzieci do 5 roku życia (Shin i in., 2008). Jednocześnie wskazuje się na obniżenie proporcji uczeń-nauczyciel oraz podniesienie jakości poprzez kwalifikacje nauczycieli i wprowadzenie bezpłatnej edukacji dla dzieci w przedziale 3-5 lat, wsparcie badań krótko- i dłu- 
goterminowych efektów edukacji wczesnoszkolnej na poziomie państwowym, a następnie odpowiednie dopasowanie rozwiązań systemowych.

\section{Metodyka badań}

Analizę zależności pomiędzy edukacją przedszkolną a wynikami nauczania na poziomie gimnazjalnym i ponadgimnazjalnym przeprowadzono adaptując wskaźnik końcowy edukacji (EI) opisany w literaturze (Arak et al., 2012, s. 42). Adaptacja polegała na zastosowaniu w omawianych wzorach odpowiednio wyników gimnazjalnych i maturalnych (liceum, technikum).

\section{Końcowy Wskaźnik Edukacji:}

$$
E I_{i}=\sqrt[2]{\mathrm{PEI}_{i} * \mathrm{PLSSEI}_{i}}
$$

gdzie:

EI - końcowy wskaźnik edukacji, PEI - wskaźnik edukacji przedszkolnej,

$$
P E I_{i}=1+99 * \frac{P E I_{e i}}{P E I_{\max }}
$$

$\mathrm{PEI}_{\mathrm{ei}}$ - odsetek dzieci w edukacji przedszkolnej w powiecie,

$\mathrm{PEI}_{\max }$ - wartość maksymalna zaobserwowana w badanym okresie,

PLSSEI $_{i}-$ wskaźnik wyników egzaminów edukacyjnych tylko z części matematyczno-przyrodniczej w gimnazjum oraz z matematyki w liceum i technikum,

$$
\text { PLSSEI }_{i}=1+99 * \frac{P L S S E I_{e i}-P L S S E I_{\text {min }}}{P L S S E I_{\text {max }}-P L S S E I_{\text {min }}}
$$

PLSSEI $_{\text {ei }}$ - odchylenie od średniej wyników egzaminu gimnazjalnego z części matematyczno-przyrodniczej, lub maturalnego z matematyki w liceum i technikum,

PLSSEI $_{\max }-$ PLSSEI $_{\min }$ - wartości odpowiednio maksymalne i minimalne analizowanych wyników egzaminacyjnych.

Dodatkowym elementem było zweryfikowanie analizowanych zależności w korelacji z poziomem rozwoju społecznego wyznaczonym w badaniach (Arak, i in., 2012, s. 13).

Miernik agregatowy wyznaczono jako pierwiastek z sumy kwadratów wielkości EI dla każdego poziomu edukacji (gimnazjum, technikum, liceum) 
i następnie podzielono przez pierwiastek z liczby 3 . Zastosowana operacja pozwala na uzyskanie miernika agregatowego o skali od 1 do 100.

Dane do prowadzonych analiz pozyskano z baz danych okręgowych komisji egzaminacyjnych oraz Banku Danych Lokalnych. Wszystkie dane zostały poddane agregacji do poziomu powiatu (NTS-4). Zastosowany poziom agregacji podyktowany był głównie sposobem organizacji szkolnictwa ponadgimnazjalnego (organem prowadzącym są jednostki samorządowe na poziomie NTS-4). Zmienne zastosowane do badań pochodziły z lat 2012-2014, z wyjątkiem wyników egzaminacyjnych, które pochodziły z roku 2015.

Wybór jednostek samorządowych do analiz został przeprowadzony losowo, wybrano po 20 powiatów z każdej z klas określających poziom rozwoju społecznego. Rozmieszczenie przestrzenne analizowanych powiatów zawiera:

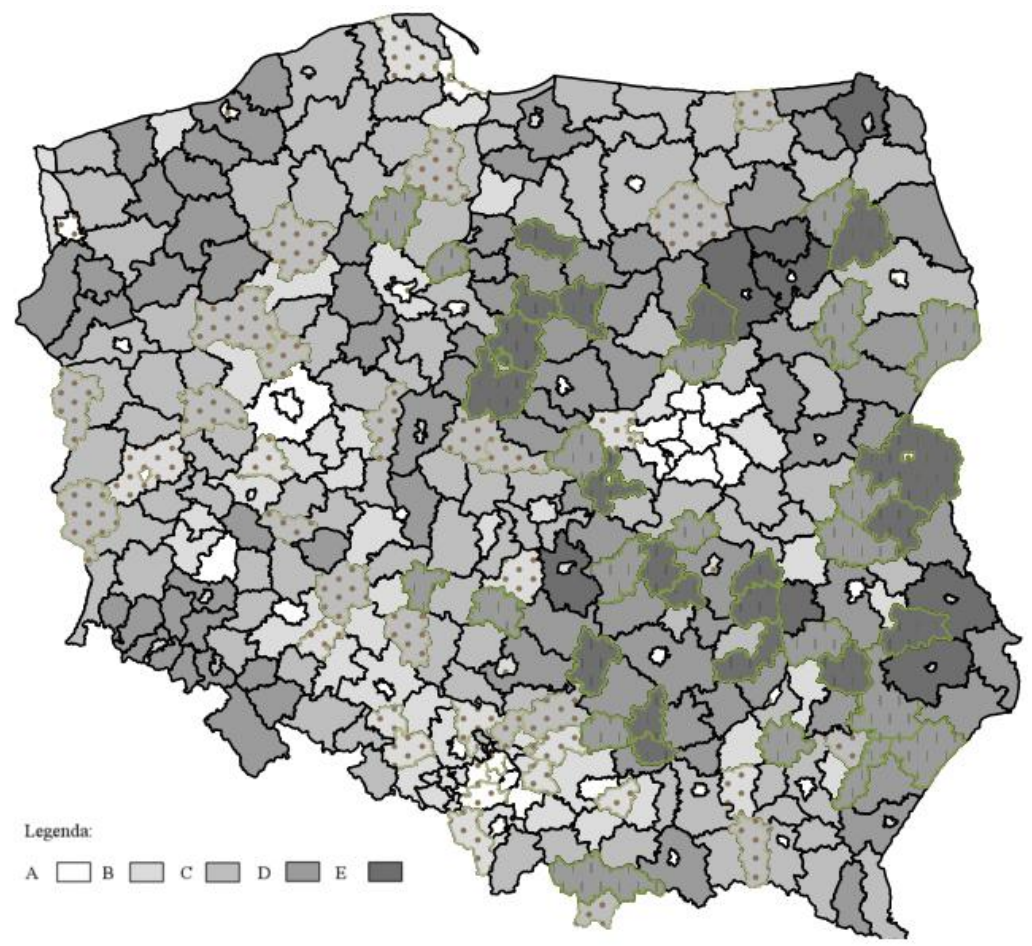

Rysunek 1. Klasy miernika społecznego (kropkami i kreskami oznaczono powiaty wybrane do analizy)

Źródło: Opracowanie własne na podstawie mapy z publikacji Krajowy Raport o Rozwoju Społecznym. Polska 2012. Rozwój regionalny i lokalny, Biuro Projektowe UNDP w Polsce, Warszawa 2012, s. 13. 
Wielkości opisujące klasy powiatów w zakresie poziomu rozwoju społecznego umieszczono w Tabeli 1.

Tabela 1. Charakterystyka klas powiatów wyznaczonych według poziomu rozwoju społecznego

\begin{tabular}{|c|c|c|c|c|}
\hline \multirow{2}{*}{$\begin{array}{c}\text { Poziom rozwoju } \\
\text { społecznego }\end{array}$} & \multicolumn{4}{|c|}{ Wartości charakterystyczne* } \\
\cline { 2 - 5 } & LHDI & HI & EI & WI \\
\hline A & 60,14 & 67,12 & 69,12 & 48,24 \\
\hline B & 48,15 & 59,07 & 52,49 & 37,23 \\
\hline C & 38,01 & 53,51 & 39,51 & 27,65 \\
\hline D & 31,42 & 46,21 & 38,33 & 19,94 \\
\hline E & 24,30 & 31,44 & 29,34 & 17,44 \\
\hline Średnia & 40,61 & 51,47 & 45,76 & 30,09 \\
\hline
\end{tabular}

"LHDI - lokalny wskaźnik rozwoju społecznego, HI-wskaźnik zdrowia, El-wskaźnik edukacji wchodzący w skład LHDI, WI-wskaźnik zamożności.

Źródło: opracowanie własne na podstawie analizowanych danych.

Szczególną uwagę skoncentrowano na wynikach dotyczących ścisłych efektów egzaminacyjnych obejmujących wyniki egzaminów z części matematycznej egzaminów gimnazjalnych i maturalnych. W wielu publikacjach wykazano, że edukacja przedszkolna może mieć wpływ na długofalowe utrzymywanie się tendencji związanych z uzyskiwanymi wynikami egzaminacyjnymi (Bartnik i in., 2011).

\section{Wyniki i dyskusja}

Analizy wartości wskaźnika edukacji (EI) w powiatach wyznaczonych według poziomu rozwoju społecznego wskazują na wyraźną polaryzację pomiędzy analizowanymi powiatami. Już w pierwszych analizach stwierdzono bowiem najwyższą wartość wskaźnika edukacji (EI) w klasie o najwyższym poziomie rozwoju społecznego oraz na wszystkich analizowanych poziomach edukacji. Omawiana tendencja w tej klasie (klasa A) została również potwierdzona najwyższą wartością miernika agregatowego. Jednocześnie w klasie E o najniższym wskaźniku rozwoju społecznego stwierdzono najniższe wartości wskaźnika edukacji (Tabela 2). 
Tabela 2. Charakterystyka wskaźnika edukacji (EI) dla klas powiatów wyznaczonych według poziomu rozwoju społecznego

\begin{tabular}{|c|c|c|c|c|}
\hline \multirow{2}{*}{$\begin{array}{c}\text { Poziom rozwoju } \\
\text { społecznego }\end{array}$} & \multicolumn{4}{|c|}{ Wskaźnik Edukacji (EI) } \\
\cline { 2 - 5 } & Gimnazjum & Liceum & Technikum & Miernik agregatowy \\
\hline A & $\uparrow 73,13$ & $\uparrow 86,50$ & $\uparrow 75,16$ & $\uparrow 78,56$ \\
\hline B & 56,54 & 75,79 & 69,98 & 68,07 \\
\hline C & 46,59 & 71,64 & 64,64 & 61,94 \\
\hline D & 54,20 & 71,94 & 65,93 & 64,66 \\
\hline E & $\downarrow 42,13$ & $\downarrow 65,35$ & $\downarrow 57,76$ & $\downarrow 56,29$ \\
\hline Średnia & 54,52 & 74,24 & 66,69 & 65,90 \\
\hline
\end{tabular}

Źródło: opracowanie własne na podstawie analizowanych danych.

Wielowymiarowe testy istotności wskazują na odrzucenie hipotezy zerowej o równości wektorów średnich pomiędzy wskaźnikiem edukacyjnym (EI) na rzecz hipotezy alternatywnej, że różnią się one istotnie, co stanowi przyczynek do potwierdzenia hipotezy postawionej we wstępie (Tabela 4).

Tabela 3. Wielowymiarowe testy istotności (wszystkie zmienne)

\begin{tabular}{|c|c|c|c|c|c|c|}
\hline & Test & Wartość & $\mathrm{F}$ & Efekt df & Błąd df & $\mathrm{p}$ \\
\hline \multirow{4}{*}{\begin{tabular}{c} 
Klasy dla poziomu rozwoju $\begin{array}{c}\text { społecznego } \\
\text { spilksa }\end{array}$ \\
\cline { 2 - 7 }
\end{tabular}} & 0,011 & 21,37 & 36 & 327,7666 & 0,00 \\
\cline { 2 - 7 } & Pillai'a & 1,783 & 8,04 & 36 & 360,0000 & 0,00 \\
\cline { 2 - 7 } & Hotelln. & 32,167 & 76,40 & 36 & 342,0000 & 0,00 \\
\cline { 2 - 7 } & Roy'a & 30,688 & 306,88 & 9 & 90,0000 & 0,00 \\
\hline
\end{tabular}

Źródło: obliczenia własne wykonane w pakiecie Statistica v.12.

Wyniki analiz jednowymiarowych wskazują na istotne zróżnicowanie wskaźnika edukacji (EI) na wszystkich analizowanych poziomach edukacji oraz wyrażone miernikiem agregatowym (Tabele 4-7).

Tabela 4. Wyniki jednowymiarowe dla zmiennych zależnych - gimnazjum

\begin{tabular}{|l|c|c|c|c|c|}
\hline \multirow{2}{*}{} & \multirow{2}{*}{$\begin{array}{c}\text { Stopnie } \\
\text { swobody }\end{array}$} & \multicolumn{4}{|c|}{ Wskaźnik Edukacji (EI) } \\
\cline { 3 - 6 } & & SS & MS & $\mathrm{F}$ & $\mathrm{p}$ \\
\hline $\begin{array}{l}\text { Klasy dla poziomu rozwoju } \\
\text { społecznego }\end{array}$ & 4 & 11334,5 & $\mathbf{2 8 3 3 , 6}$ & $\mathbf{8 0 , 4 3 0}$ & $\mathbf{0 , 0 0}$ \\
\hline Błąd & 95 & 3347,0 & 35,2 & & \\
\hline Ogółem & 99 & 14681,5 & & & \\
\hline
\end{tabular}

Źródło: obliczenia własne wykonane w pakiecie Statistica v.12. 
Tabela 5. Wyniki jednowymiarowe dla zmiennych zależnych - liceum

\begin{tabular}{|l|c|c|c|c|c|}
\hline & \multirow{2}{*}{$\begin{array}{c}\text { Stopnie } \\
\text { swobody }\end{array}$} & \multicolumn{4}{|c|}{ Wskaźnik Edukacji (EI) } \\
\cline { 3 - 6 } & & SS & MS & F & P \\
\hline $\begin{array}{l}\text { Klasy dla poziomu rozwoju } \\
\text { społecznego }\end{array}$ & 4 & 4876,8 & 1219,2 & 36,69 & 0,00 \\
\hline Błąd & 95 & 3156,8 & 33,2 & & \\
\hline Ogółem & 99 & 8033,6 & & & \\
\hline
\end{tabular}

Źródło: obliczenia własne wykonane w pakiecie Statistica v.12.

Tabela 6. Wyniki jednowymiarowe dla zmiennych zależnych - technikum

\begin{tabular}{|l|c|c|c|c|c|}
\hline & \multirow{2}{*}{$\begin{array}{c}\text { Stopnie } \\
\text { swobody }\end{array}$} & \multicolumn{4}{|c|}{ Wskaźnik Edukacji (EI) } \\
\cline { 3 - 6 } & & SS & MS & F & P \\
\hline $\begin{array}{l}\text { Klasy dla poziomu rozwoju } \\
\text { społecznego }\end{array}$ & 4 & 3342,5 & 835,6 & 18,259 & 0,0000 \\
\hline Błąd & 95 & 4347,7 & 45,8 & & \\
\hline Ogółem & 99 & 7690,1 & & & \\
\hline
\end{tabular}

Źródło: obliczenia własne wykonane w pakiecie Statistica v.12.

Tabela 7. Wyniki jednowymiarowe dla zmiennych zależnych - miernik agregatowy

\begin{tabular}{|l|c|c|c|c|c|}
\hline & \multirow{2}{*}{$\begin{array}{c}\text { Stopnie } \\
\text { swobody }\end{array}$} & \multicolumn{4}{|c|}{ Wskaźnik Edukacji (EI) } \\
\cline { 3 - 6 } & & SS & MS & F & P \\
\hline $\begin{array}{l}\text { Klasy dla poziomu rozwoju } \\
\text { społecznego }\end{array}$ & 4 & 5487,2 & 1371,8 & $\mathbf{9 3 , 4 8}$ & 0,00 \\
\hline Błąd & 95 & 1394,0 & 14,7 & & \\
\hline Ogółem & 99 & 6881,2 & & & \\
\hline
\end{tabular}

Źródło: obliczenia własne wykonane w pakiecie Statistica v.12.

Testy post-hoc wykazały, że istotne znaczenie dla wskaźnika edukacji (EI) w gimnazjum ma zmiana klasy poziomu rozwoju społecznego pomiędzy klasą A i pozostałymi klasami. Wskaźnik edukacji (EI) jest istotnie różnicowany pomiędzy klasą $\mathrm{B}$ a $\mathrm{C}$ oraz $\mathrm{A}$. Istotne zróżnicowanie wskaźnika edukacji (EI) wyznaczonego dla gimnazjum występuje pomiędzy klasą $\mathrm{C}$ a klasami: A, B, D. Analiza istotności pomiędzy klasą D a pozostałymi klasami wskazuje tylko na brak istotnego zróżnicowania w stosunku do klasy B. Klasa $\mathrm{E}$ jest istotnie zróżnicowana $\mathrm{W}$ stosunku do wszystkich klas, poza klasą $\mathrm{C}$ (Tabela 8). 
Tabela 8. Test HSD Tukeya - zmienna „Wskaźnik Edukacji (EI) - gimnazjum”

\begin{tabular}{|c|c|c|c|c|c|c|}
\hline Lp. & $\begin{array}{c}\text { Poziom rozwoju } \\
\text { społecznego }\end{array}$ & A & B & C & D & E \\
\hline 1. & A & & 0,000117 & 0,000117 & 0,000117 & $\mathbf{0 , 0 0 0 1 1 7}$ \\
\hline 2. & B & 0,000117 & & $\mathbf{0 , 0 0 0 1 2 3}$ & 0,724370 & 0,000117 \\
\hline 3. & C & 0,000117 & 0,000123 & & $\mathbf{0 , 0 0 1 0 4 3}$ & 0,132303 \\
\hline 4. & D & $\mathbf{0 , 0 0 0 1 1 7}$ & 0,724370 & $\mathbf{0 , 0 0 1 0 4 3}$ & & $\mathbf{0 , 0 0 0 1 1 7}$ \\
\hline 5. & E & $\mathbf{0 , 0 0 0 1 1 7}$ & $\mathbf{0 , 0 0 0 1 1 7}$ & 0,132303 & $\mathbf{0 , 0 0 0 1 1 7}$ & \\
\hline
\end{tabular}

przybliżone prawdopodobieństwo dla testów post hoc; błąd: MS międzygrupowe $=35,231$, df $=95,000$ Źródło: obliczenia własne wykonane w pakiecie Statistica v.12.

Analiza za pomocą testów post-hoc zastosowana w stosunku do wskaźnika edukacji (EI) na poziomie liceum wskazuje na istotne zróżnicowanie pomiędzy skrajnymi klasami poziomu rozwoju społecznego a pozostałymi klasami (Tabela 9).

Tabela 9. Test HSD Tukeya - zmienna „Wskaźnik Edukacji (EI) - liceum

\begin{tabular}{|c|c|c|c|c|c|c|}
\hline Lp. & $\begin{array}{c}\text { Poziom rozwoju } \\
\text { społecznego }\end{array}$ & A & B & C & D & E \\
\hline 1. & A & & 0,000118 & 0,000117 & 0,000117 & 0,000117 \\
\hline 2. & B & 0,000118 & & 0,160610 & 0,222035 & 0,000118 \\
\hline 3. & C & 0,000117 & 0,160610 & & 0,999854 & 0,007395 \\
\hline 4. & D & 0,000117 & 0,222035 & 0,999854 & & 0,004408 \\
\hline 5. & E & 0,000117 & 0,000118 & 0,007395 & 0,004408 & \\
\hline \multicolumn{2}{|r|}{ przybliżone prawdopodobieństwo dla testów post hoc; błąd: MS międzygrupowe $=33,229, \mathrm{df}=95,000$} \\
\hline
\end{tabular}

Źródło: obliczenia własne wykonane w pakiecie Statistica v.12.

Analiza za pomocą testów post-hoc zastosowana w stosunku do wskaźnika edukacji (EI) na poziomie technikum wskazuje na istotne zróżnicowanie pomiędzy klasą A oraz klasami C, D, E oraz klasą E i pozostałymi klasami wyznaczonymi według wskaźnika rozwoju społecznego (Tabela 10).

Tabela 10. Test HSD Tukeya - zmienna „Wskaźnik Edukacji (EI) - technikum

\begin{tabular}{|c|c|c|c|c|c|c|}
\hline Lp. & $\begin{array}{c}\text { Poziom rozwoju } \\
\text { społecznego }\end{array}$ & A & B & C & D & E \\
\hline 1. & A & & 0,118765 & $\mathbf{0 , 0 0 0 1 4 7}$ & $\mathbf{0 , 0 0 0 4 8 3}$ & $\mathbf{0 , 0 0 0 1 1 7}$ \\
\hline 2. & B & 0,118765 & & 0,100243 & 0,327731 & $\mathbf{0 , 0 0 0 1 1 8}$ \\
\hline
\end{tabular}


Tabela 10. Test HSD Tukeya - zmienna „Wskaźnik Edukacji (EI) - technikum cd.

\begin{tabular}{|c|c|c|c|c|c|c|}
\hline Lp. & $\begin{array}{c}\text { Poziom rozwoju } \\
\text { społecznego }\end{array}$ & A & B & C & D & E \\
\hline 3. & C & $\mathbf{0 , 0 0 0 1 4 7}$ & 0,100243 & & 0,974527 & $\mathbf{0 , 0 1 4 9 6 9}$ \\
\hline 4. & D & $\mathbf{0 , 0 0 0 4 8 3}$ & 0,327731 & 0,974527 & & $\mathbf{0 , 0 0 2 2 9 0}$ \\
\hline 5. & E & 0,000117 & 0,000118 & 0,014969 & 0,002290 & \\
\hline
\end{tabular}

przybliżone prawdopodobieństwo dla testów post hoc; błąd: MS międzygrupowe $=45,765, \mathrm{df}=95,000$

Źródło: obliczenia własne wykonane w pakiecie Statistica v.12.

Analiza za pomocą testów post-hoc zastosowana w stosunku do wskaźnika edukacji (EI) dla miernika agregatowego wskazuje na istotne zróżnicowanie pomiędzy wszystkimi klasami, z wyjątkiem klasy C oraz D (Tabela 11).

Tabela 11. Test HSD Tukeya - zmienna „Wskaźnik Edukacji (EI) - miernik agregatowy"

\begin{tabular}{|c|c|c|c|c|c|c|}
\hline Lp. & $\begin{array}{c}\text { Poziom rozwoju } \\
\text { społecznego }\end{array}$ & A & B & C & D & E \\
\hline 1. & A & & 0,000117 & 0,000117 & 0,000117 & 0,000117 \\
\hline 2. & B & 0,000117 & & 0,000133 & 0,046366 & 0,000117 \\
\hline 3. & C & 0,000117 & 0,000133 & & 0,171327 & 0,000207 \\
\hline 4. & D & 0,000117 & 0,046366 & 0,171327 & & 0,000117 \\
\hline 5. & E & 0,000117 & 0,000117 & 0,000207 & 0,000117 & \\
\hline
\end{tabular}

przybliżone prawdopodobieństwo dla testów post hoc; błąd: MS międzygrupowe $=14,674$, df $=95,000$

Źródło: obliczenia własne wykonane w pakiecie Statistica v.12.

Zastosowana analiza kontrastów dla wskaźnika edukacji (EI) dla gimnazjum wskazuje, że zmiana klasy poziomu rozwoju społecznego z A na E wyjaśnia 71,23\% wskaźnika edukacji (EI). Wspomniana zmiana stanowi najbardziej jaskrawe wskazanie na znaczenie klasy miernika społecznego dla miernika edukacji (EI). Zmiana pozostałych klas na klasę E wskazuje na wyjaśnienie, w przypadku klasy B $-15,53 \%, \mathrm{C}-1,49 \%$, D-10,85\%. Wyznaczony dla tego kontrastu wskaźnik $₫$ wynosi 0,76 , co oznacza, że zmiana poziomu rozwoju społecznego wyjaśnia 76\% zmienności wskaźnika edukacji (EI) dla gimnazjum (Tabela 12). 
Tabela 12. Ocena kontrastów dla Wskaźnika Edukacji (EI) - gimnazjum

\begin{tabular}{|c|c|c|c|c|c|c|}
\hline & \multicolumn{4}{|c|}{ Wskaźnik Edukacji (El) } & \multirow{2}{*}{$\begin{array}{l}\text { Gr. ufn. } \\
-95,00 \%\end{array}$} & \multirow{2}{*}{$\begin{array}{c}\text { Gr. ufn. } \\
+95,00 \%\end{array}$} \\
\hline & Ocena & Bł. std. & $\mathrm{T}$ & $\mathrm{p}$ & & \\
\hline $\begin{array}{c}\text { KONTR. } 1 \\
\text { (A vs. } \mathrm{E}, \mathrm{t} \text {.j. } 1 ; 0 ; 0 ; 0 ;-1 \text { ) }\end{array}$ & 30,99142 & 1,876995 & 16,51119 & 0,000000 & 27,26511 & 34,71772 \\
\hline${ }^{*} \mathrm{SS}_{\mathrm{kontras}} / \mathrm{SS}_{\text {efekt }}$ & \multicolumn{6}{|c|}{$3,39(72,13 \%)$} \\
\hline $\begin{array}{c}\text { KONTR. } 2 \\
\text { (B vs. E, tj. } 0 ; 1 ; 0 ; 0 ;-1 \text { ) }\end{array}$ & 14,40860 & 1,876995 & 7,67642 & 0,000000 & 10,68230 & 18,13491 \\
\hline${ }^{*} \mathrm{SS}_{\text {kontrast }} / \mathrm{SS}_{\text {efekt }}$ & \multicolumn{6}{|c|}{$0,73(15,53 \%)$} \\
\hline $\begin{array}{c}\text { KONTR. } 3 \\
\text { (C vs. E, tj. } 0 ; 0 ; 1 ; 0 ;-1) \\
\end{array}$ & 4,45132 & 1,876995 & 2,37152 & 0,019733 & 0,72502 & 8,17763 \\
\hline${ }^{*} \mathrm{SS}_{\text {kontrast }} / \mathrm{SS}_{\text {efekt }}$ & \multicolumn{6}{|c|}{$0,07(1,49 \%)$} \\
\hline $\begin{array}{c}\text { KONTR. } 4 \\
\text { (D vs. E, tj. } 0 ; 0 ; 0 ; 1 ;-1 \text { ) }\end{array}$ & 12,06931 & 1,876995 & 6,43012 & 0,000000 & 8,34300 & 15,79562 \\
\hline${ }^{*} \mathrm{SS}_{\text {kontrast }} / \mathrm{SS}_{\text {efekt }}$ & \multicolumn{6}{|c|}{$0,51(10,85 \%)$} \\
\hline
\end{tabular}

Źródło: obliczenia własne wykonane w pakiecie Statistica v.12.

Zastosowana analiza kontrastów dla wskaźnika edukacji (EI) dla liceum wskazuje, że zmiana klasy poziomu rozwoju społecznego z A na E wyjaśnia 69,90\% wskaźnika edukacji (EI). Wspomniana zmiana stanowi najbardziej jaskrawe wskazanie na znaczenie klasy miernika społecznego dla miernika edukacji (EI). Zmiana pozostałych klas na klasę E wskazuje na wyjaśnienie, w przypadku klasy B - 17,14\%, C-6,10\%, D-6,86\%. Wyznaczony dla tego kontrastu wskaźnik @ wynosi 0,59 , co oznacza, że zmiana poziomu rozwoju społecznego wyjaśnia 59\% zmienności wskaźnika edukacji (EI) dla liceum (Tabela 13).

Tabela 13. Ocena kontrastów dla Wskaźnika Edukacji (El) - liceum

\begin{tabular}{|c|c|c|c|c|c|c|}
\hline & \multicolumn{4}{|c|}{ Wskaźnik Edukacji (El) } & \multirow{2}{*}{$\begin{array}{l}\text { Gr. ufn. } \\
-95,00 \% \\
\end{array}$} & \multirow{2}{*}{$\begin{array}{c}\text { Gr. ufn. } \\
+95,00 \%\end{array}$} \\
\hline & Ocena & Bł. Std. & $T$ & $\mathrm{p}$ & & \\
\hline $\begin{array}{c}\text { KONTR. } 1 \\
\text { (A vs. E, tj. } 1 ; 0 ; 0 ; 0 ;-1 \text { ) }\end{array}$ & 21,15119 & 1,822892 & 11,60309 & 0,000000 & 17,53229 & 24,77008 \\
\hline${ }^{*} \mathrm{SS}_{\text {kontrast }} / \mathrm{SS}_{\text {efekt }}$ & \multicolumn{6}{|c|}{$3,67(69,90 \%)$} \\
\hline $\begin{array}{c}\text { KONTR. } 2 \\
\text { (B vs. E, tj. } 0 ; 1 ; 0 ; 0 ;-1 \text { ) }\end{array}$ & 10,44670 & 1,822892 & 5,73084 & 0,000000 & 6,82780 & 14,06560 \\
\hline${ }^{*} \mathrm{SS}_{\text {kontrast }} / \mathrm{SS}_{\text {efekt }}$ & \multicolumn{6}{|c|}{$0,90(17,14 \%)$} \\
\hline $\begin{array}{c}\text { KONTR. } 3 \\
\text { (C vs. E, tj. } 0 ; 0 ; 1 ; 0 ;-1 \text { ) }\end{array}$ & 6,29071 & 1,822892 & 3,45095 & 0,000835 & 2,67182 & 9,90961 \\
\hline${ }^{*} \mathrm{SS}_{\text {kontrast }} / \mathrm{SS}_{\text {efekt }}$ & \multicolumn{6}{|c|}{$0,32(6,10 \%)$} \\
\hline
\end{tabular}


Tabela 13. Ocena kontrastów dla Wskaźnika Edukacji (EI) - liceum cd.

\begin{tabular}{|c|c|c|c|c|c|c|}
\hline & \multicolumn{4}{|c|}{ Wskaźnik Edukacji (EI) } & Gr. ufn. & Gr. ufn. \\
\hline & Ocena & Bł. Std. & $\mathrm{T}$ & $\mathrm{p}$ & $-95,00 \%$ & $+95,00 \%$ \\
\hline $\begin{array}{c}\text { KONTR. } 4 \\
\text { (D vs. E, tj. } 0 ; 0 ; 0 ; 1 ;-1)\end{array}$ & 6,58971 & 1,822892 & 3,61498 & 0,000483 & 2,97081 & 10,20861 \\
\hline${ }^{*} S S_{\text {kontrast }} / S S_{\text {efekt }}$ & \multicolumn{6}{|c|}{$0,36(6,86 \%)$} \\
\hline
\end{tabular}

Źródło: obliczenia własne wykonane w pakiecie Statistica v.12.

Zastosowana analiza kontrastów dla wskaźnika edukacji (EI) dla technikum wskazuje, że zmiana klasy poziomu rozwoju społecznego z A na E wyjaśnia 53,39\% wskaźnika edukacji (EI). Wspomniana zmiana stanowi najbardziej jaskrawe wskazanie na znaczenie klasy miernika społecznego dla miernika edukacji (EI). Zmiana pozostałych klas na klasę E wskazuje na wyjaśnienie, w przypadku klasy B $-26,40 \%$, C- $8,41 \%$, D- $11,80 \%$. Wyznaczony dla tego kontrastu wskaźnik $₫$ wynosi 0,41 , co oznacza, że zmiana poziomu rozwoju społecznego wyjaśnia $41 \%$ zmienności wskaźnika edukacji (EI) dla technikum (Tabela 14).

Tabela 14. Ocena kontrastów dla Wskaźnika Edukacji (EI) - technikum

\begin{tabular}{|c|c|c|c|c|c|c|}
\hline & \multicolumn{4}{|c|}{ Wskaźnik Edukacji (El) } & Gr. ufn. & Gr. ufn. \\
\hline & Ocena & Bł. Std. & $\mathrm{T}$ & $\mathrm{p}$ & $-95,00 \%$ & $+95,00 \%$ \\
\hline $\begin{array}{c}\text { KONTR. } 1 \\
\text { (A vs. E, tj. } 1 ; 0 ; 0 ; 0 ;-1 \text { ) } \\
\end{array}$ & 17,40172 & 2,139277 & 8,134396 & 0,000000 & 13,15472 & 21,64872 \\
\hline${ }^{*} \mathrm{SS}_{\text {kontras }} / \mathrm{SS}_{\text {efekt }}$ & \multicolumn{6}{|c|}{$3,62(53,39 \%)$} \\
\hline $\begin{array}{c}\text { KONTR. } 2 \\
\text { (B vs. E, tj. } 0 ; 1 ; 0 ; 0 ;-1 \text { ) } \\
\end{array}$ & 12,22308 & 2,139277 & 5,713653 & 0,000000 & 7,97608 & 16,47009 \\
\hline${ }^{*} S S_{\text {kontrast }} / S S_{\text {efekt }}$ & \multicolumn{6}{|c|}{$1,79(26,40 \%)$} \\
\hline $\begin{array}{c}\text { KONTR. } 3 \\
\text { (C vs. E, tj. } 0 ; 0 ; 1 ; 0 ;-1 \text { ) } \\
\end{array}$ & 6,88354 & 2,139277 & 3,217695 & 0,001768 & 2,63654 & 11,13054 \\
\hline${ }^{*} \mathrm{SS}_{\text {kontrast }} / \mathrm{SS}_{\text {efekt }}$ & \multicolumn{6}{|c|}{$0,57(8,41 \%)$} \\
\hline $\begin{array}{c}\text { KONTR. } 4 \\
\text { (D vs. E, tj. } 0 ; 0 ; 0 ; 1 ;-1 \text { ) } \\
\end{array}$ & 8,17122 & 2,139277 & 3,819619 & 0,000238 & 3,92422 & 12,41822 \\
\hline${ }^{*} \mathrm{SS}_{\text {kontrast }} / \mathrm{SS}_{\text {efekt }}$ & \multicolumn{6}{|c|}{$0,80(11,80 \%)$} \\
\hline
\end{tabular}

Źródło: obliczenia własne wykonane w pakiecie Statistica v.12.

Zastosowana analiza kontrastów dla wskaźnika edukacji (EI) dla miernika agregatowego wskazuje, że zmiana klasy poziomu rozwoju społecznego z A na E wyjaśnia $67,35 \%$ wskaźnika edukacji (EI). Wspomniana zmiana stanowi 
najbardziej jaskrawe wskazanie na znaczenie klasy miernika społecznego dla miernika edukacji (EI). Zmiana pozostałych klas na klasę E wskazuje na wyjaśnienie, w przypadku klasy B - 18,84\%, C-4,29\%, D-9,51\%. Wyznaczony dla tego kontrastu wskaźnik @ wynosi 0,79 , co oznacza, że zmiana poziomu rozwoju społecznego wyjaśnia 79\% zmienności wskaźnika edukacji (EI) dla wszystkich poziomów kształcenia (Tabela 15).

Tabela 15. Ocena kontrastów dla Wskaźnika Edukacji (EI) - miernik agregatowy

\begin{tabular}{|c|c|c|c|c|c|c|}
\hline & \multicolumn{4}{|c|}{ Wskaźnik Edukacji (El) } & Gr. ufn. & Gr. ufn. \\
\hline & Ocena & Bt. Std. & $T$ & $\mathrm{p}$ & $-95,00 \%$ & $+95,00 \%$ \\
\hline $\begin{array}{c}\text { KONTR. } 1 \\
\text { (A vs. } \mathrm{E}, \mathrm{t} \text { t. } 1 ; 0 ; 0 ; 0 ;-1 \text { ) }\end{array}$ & 22,26124 & 1,211363 & 18,37702 & 0,000000 & 19,85638 & 24,66609 \\
\hline${ }^{*} \mathrm{SS}_{\text {kontrast }} / \mathrm{SS}_{\text {efekt }}$ & \multicolumn{6}{|c|}{$3,61(67,35 \%)$} \\
\hline $\begin{array}{c}\text { KONTR. } 2 \\
\text { (B vs. E, tj. } 0 ; 1 ; 0 ; 0 ;-1 \text { ) } \\
\end{array}$ & 11,77179 & 1,211363 & 9,71781 & 0,000000 & 9,36693 & 14,17665 \\
\hline${ }^{*} S S_{\text {kontrast }} / S S_{\text {efekt }}$ & \multicolumn{6}{|c|}{$1,01(18,84 \%)$} \\
\hline $\begin{array}{c}\text { KONTR. } 3 \\
\text { (C vs. E, tj. } 0 ; 0 ; 1 ; 0 ;-1)\end{array}$ & 5,64332 & 1,211363 & 4,65865 & 0,000010 & 3,23846 & 8,04818 \\
\hline${ }^{*} \mathrm{SS}_{\text {kontrast }} / \mathrm{SS}_{\text {efekt }}$ & \multicolumn{6}{|c|}{$0,23(4,29 \%)$} \\
\hline $\begin{array}{c}\text { KONTR. } 4 \\
\text { (D vs. E, tj. } 0 ; 0 ; 0 ; 1 ;-1)\end{array}$ & 8,36686 & 1,211363 & 6,90699 & 0,000000 & 5,96201 & 10,77172 \\
\hline${ }^{*} \mathrm{SS}_{\text {kontrast }} / \mathrm{SS}_{\text {efekt }}$ & \multicolumn{6}{|c|}{$0,51(9,51 \%)$} \\
\hline
\end{tabular}

Źródło: obliczenia własne wykonane w pakiecie Statistica v.12.

\section{Zakończenie}

Analizy przeprowadzone w niniejszej pracy stanowią początkowy etap do bardziej pogłębionych badań nad wpływem poziomu rozwoju społecznego oraz edukacji przedszkolnej na osiągnięcia edukacyjne uczniów na wszystkich poziomach kształcenia.

Przeprowadzone badania pozwalają na wskazanie wstępnych sugestii (wniosków), że występuje istotne zróżnicowanie pomiędzy poziomem rozwoju społecznego na wszystkich analizowanych etapach edukacji (gimnazjum, liceum, technikum), a wskaźnikiem edukacji. Wynika $\mathrm{z}$ tego konieczność szczególnej dbałości o dostępność edukacji przedszkolnej (wielkość uwzględniana we wskaźniku edukacji) oraz konieczność wypracowania metod dodatkowego wsparcia dydaktycznego $\mathrm{w}$ regionach o niższym poziomie rozwoju społecznego. 
Należy jednak jeszcze raz podkreślić, że uzyskane wyniki analiz są tylko wskazówką do przeprowadzenia dalszych, pogłębionych badań, których celem powinno być potwierdzenie wstępnych wyników uzyskanych w niniejszej pracy.

\section{Bibliografia:}

Ade, A., Gupta, S.S., Maliye, C., Deshmukh, P.R., Garg, B.S. (2010), Effect of improvement of pre-school education through Anganwadi center on intelligence and development quotient of children, "Indian Journal of Pediatrics", 77(5), s. 541-546. http://doi. org/10.1007/s12098-010-0056-7.

Aguilar, R., Tansini, R. (2012), Joint analysis of preschool attendance and school performance in the short and long-run, "International Journal of Educational Development", 32(2), s. 224-231. http://doi.org/10.1016/j.ijedudev.2011.03.001.

Apps, P., Mendolia, S., Walker, I. (2013), The impact of pre-school on adolescents' outcomes: Evidence from a recent English cohort, "Economics of Education Review", 37, s. 183-199. http://doi.org/10.1016/ j.econedurev.2013.09.006.

Arak, P., Ivanov, A., Peleah, M., Płoszaj, A., Rakocy, K., Rok, J., Wyszkowski, K. (2012), Krajowy Raport o Rozwoju Społecznym Polska 2012. Rozwój regionalny i lokalny, Issuu. Pobrano z https://issuu.com/undp_poland/ docs/raport_lhdi.

Bartnik, E. (2011), Społeczeństwo w drodze do wiedzy. Raport o stanie edukacji, Instytut Badań Edukacyjnych, Warszawa.

Becker, B. (2011), Social disparities in children's vocabulary in early childhood. Does pre-school education help to close the gap? "British Journal of Sociology", 62(1), s. 69-88. http://doi.org/10.1111/j.1468-4446.2010.01345.x.

Campos, M.M., Bhering, E.B., Esposito, Y., Gimenes, N., Abuchaim, B., Valle, R., Unbehaum, S. (2011), A contribuição da educação infantil de qualidade e seus impactos no início do ensino fundamental, "Educação e Pesquisa", 37(1), s. 15-33. http://doi. org/10.1590/S1517-97022011000100002.

Correia, K., Marques-Pinto, A. (2016), ,, Giant Leap 1”: A Social and Emotional Learning program's effects on the transition to first grade, "Children and Youth Services Review", 61, s. 61-68. http://doi.org/10.1016/j.childyouth.2015.12.002.

Daniels, S. (1995), Can Preschool Education Affect Childrens Achievement in Primary-School. "Oxford Review of Education", 21(2), s. 163-178. http://doi.org/10. 1080/0305498950210203.

Davis, J. (2009), Revealing the research , hole” of early childhood education for sustainability: a preliminary survey of the literature, "Environmental Education Research", 15(2), s. 227-241. http://doi.org/10.1080/13504620802710607. 
Dereli-Iman, E. (2014), The Effect of the Values Education Programme on 5.5-6 Year old Children's Social Development: Social Skills, Psycho-social Development and Social Problem Solving Skills, "Kuram Ve Uygulamada Egitim Bilimleri”, 14(1), s. 262-268 .

Gonzalez-Betancor, S.M., Lopez-Puig, A.J. (2015), Early schooling: its influence on reading comprehension at primary level. "Cultura Y Educacion”, 27(2), s. 237-270. http://doi. org/10.1080/11356405.2015.1034533.

Hall, J., Sylva, K., Melhuish, E., Sammons, P., Siraj-Blatchford, I., Taggart, B. (2009), The role of pre-school quality in promoting resilience in the cognitive development of young children, "Oxford Review of Education", 35(3), s. 331-352. http://doi. org/10.1080/03054980902934613.

Hansen, K. (2014), Moving house for education in the pre-school years, "British Educational Research Journal”, 40(3), s. 483-500. http://doi.org/10.1002/berj.3092.

Jerrim, J., Choi, A. (2014), The mathematics skills of school children: how does England compare to the high-performing East Asian jurisdictions? "Journal of Education Policy”, 29(3), s. 349-376. http://doi.org/10.1080/02680939.2013.831950.

Kutnick, P. (2000), Girls, boys and school achievement - Critical comments on who achieves in schools and under what economic and social conditions achievement takes placea Caribbean perspective, "International Journal of Educational Development", 20(1), s. 65-84. http://doi.org/10.1016/S0738-0593(99)00045-0.

Lagerberg, D. (2000), Secondary prevention in child health: effects of psychological intervention, particularly home visitation, on children's development and other outcome variables, "Acta Paediatrica", 89, s. 43-52. http://doi.org/10.1080/080352500750027394.

Melhuish, E., Quinn, L., Sylva, K., Sammons, P., Siraj-Blatchford, I., Taggart, B. (2013), Preschool affects longer term literacy and numeracy: results from a general population longitudinal study in Northern Ireland, "School Effectiveness and School Improvement”, 24(2), s. 234-250. http://doi.org/10.1080/09243453.2012.749796.

Sammons, P., Anders, Y., Sylva, K., Melhuish, E., Siraj-Blatchford, I., Taggart, B., Barreau, S. (2008), Children's Cognitive Attainment and Progress in English Primary Schools During Key Stage 2: Investigating the potential continuing influences of pre-school education, "Zeitschrift Fur Erziehungswissenschaft", 10, s. 179-198.

Samusevica, A. (2013), Empiric dimension of educational quality at preschool, "Society, Integration, Education”, 2013, Vol I (ss. 381-389), Rezekne: Rezekne Higher Educ Inst-Rezeknes Augstskola.

Shin, E., Chung, M., Park, E., Kwon, J.Y., 전홍주. (2008), Review of Research on the Effects of Early Childhood Education conducted in the U.S. and U. K.: Implications for Ko- 
rean Early Childhood Education, "Early Childhood Education Research \& Review", 12(5), s. 451-471.

Sylva, K. (2014), The role of families and pre-school in educational disadvantage, "Oxford Review of Education", 40(6), s. 680-695. http://doi.org/10.1080/03054985.2014.979581.

Taiwo, A.A., Tyolo, J.B. (2002), The effect of pre-school education on academic performance in primary school: a case study of grade one pupils in Botswana, "International Journal of Educational Development”, 22(2), s. 169-180. http://doi.org/10.1016/ /S0738-0593(01)00020-7.

Tatari, F., Pashabadi, M., Farnia, V., Nouri, T., Hossieni, M., Roshani, D. (2013), The effect of pre-school education on social maturity of elementary students, "Journal of the Pakistan Medical Association”, 63(8), s. 980-982.

Taylor, A. (2010), Here and now: the attendance issue in Indigenous early childhood education, "Journal of Education Policy", 25(5), s. 677-699. http://doi.org/10.1080/026809 39.2010 .493225 .

Washbrook, E., Propper, C., Sayal, K. (2013), Pre-school hyperactivity/attention problems and educational outcomes in adolescence: prospective longitudinal study, "British Journal of Psychiatry”, 203(4), s. 265-271. http://doi.org/10.1192/bjp.bp.112.123562. 